\title{
Sinilupiinin (Lupinus Angustifolius) vaikutus munivien kanojen tuotantoon ja munan laatuun
}

\author{
Petra Tuunainen $^{1)}$, Erja Koivunen ${ }^{1)}$, Jarmo Valaja ${ }^{2)}$ \\ ${ }^{1)}$ Maa- ja elintarviketalouden tutkimuskeskus MTT, Animale, 31600 Jokioinen, etuni- \\ mi.sukunimi@mtt.fi \\ ${ }^{2)}$ Helsingin yliopisto, Maataloustieteen laitos, Koetilantie 5, 00014 Helsingin yliopisto, etuni- \\ mi.sukunimi@helsinki.fi
}

\section{TIIVISTELMÄ}

Sinilupiini on typpeä sitova palkokasvi. Sen viljelyä on tähän asti rajoittanut pitkä kasvuaika ja siitä aiheutuva viljelyepävarmuus, mutta valkuaisomavaraisuuden tehostamistavoitteet ovat viime vuosina lisänneet kiinnostusta sinilupiinin viljelyyn ja käyttöön rehuvalkuaisen lähteenä. Sinilupiinissa on kuitenkin vain vähän rikkipitoisia aminohappoja ja se sisältää paljon kuitua, mikä rajoittaa sen käyttöä siipikarjan ruokinnassa. Aikaisemmissa kokeissa sinilupiinin sulavuus ja muuntokelpoinen energia olivat broilereilla ja kalkkunoilla heikkoja verrattuna härkäpapuun tai herneeseen. Munivilla kanoilla lupiinilisäys ei vaikuttanut munantuotantoon, kun käyttötaso oli $15 \%$, mutta suurempi määrä vähensi selvästi munintaa. Tutkimuksen tarkoituksena oli selvittää rajoitetulla kanamäärällä sinilupiinin vaikutuksia munantuotantoon ja kanamunan laatuun, erityisesti keltuaisen väriin.

Kokeessa oli 108 LSL- kanaa, jotka kokeen alkaessa olivat 40 viikon ikäisiä. Kanat jaettiin koehäkkeihin 3 kanaa per häkki. Koe kesti 6 viikkoa. Koeryhmien kanojen rehuihin lupiinia lisättiin 0, 8 tai $16 \%$. Kokeessa havaittiin, että kontrolliryhmän munintaprosentti oli huomattavasti pienempi kuin sinilupiiniryhmien munintaprosentit $(\mathrm{P}<0,0001)$. Munien tuotanto $(\mathrm{g} / \mathrm{pv} / \mathrm{kana})$ parani lintujen syödessä sinilupiinia $(\mathrm{P}=0,019)$ ja samalla rehunmuuntosuhde $(\mathrm{kg} /$ muna-kg) pieneni $(\mathrm{P}=0,015)$, koska rehunkulutus (g/pv/kana) ei eronnut ryhmien välillä. Sinilupiinirehuilla ruokitut linnut munivat Haughluvultaan suurempia munia kuin kontrolliryhmä. Sinilupiinin määrällä ei havaittu olevan vaikutusta tuotantotuloksiin Tuotannon parantuminen saattoi johtua osittain eläinten välisestä vaihtelusta, ei niiinkään sinilupiinin munintaa parantavasta vaikutuksesta.

Sinilupiini näyttäisi kuitenkin maistuvan kanoille ja sopivan hyvin munivien kanojen valkuaisrehuksi. Sinilupiinia voidaan tämän kokeen perusteella käyttää munivien kanojen dieetissä ainakin 16 \% ilman, että tuotantotulokset huononevat. Sinilupiinia syövät kanat voivat munia keltuaisen väriltään, punaisempi munia kuin tavanomaista rehua syövät kanat.

Asiasanat: $\quad$ sinilupiini, $\quad$ kana, munantuotanto, valkuaiskasvit 


\section{JOHDANTO}

Sinilupiini on typpeä sitova palkokasvi. Sen viljelyä on tähän asti rajoittanut pitkä kasvuaika ja siitä aiheutuva viljelyepävarmuus, mutta valkuaisomavaraisuuden tehostamistavoitteet ovat viime vuosina lisänneet kiinnostusta sinilupiinin viljelyyn ja käyttöön rehuvalkuaisen lähteenä.

MTT:llä 2000-luvun alussa tehdyissä sulavuuskokeissa sinilupiinin sulavuus ja muuntokelpoinen energia-arvo broilereilla ja kalkkunoilla (Palander ym. 2006) olivat heikkoja verrattuna härkäpapuun tai herneeseen. Lupiinilisäys ei vaikuttanut munantuotantoon, kun käyttötaso oli $15 \%$, mutta suurempi määrä (25 \%) vähensi selvästi munintaa (Hammersjoi \& Steenfeld 2005). Hammersjoin ja Steenfeldin (2005) tutkimuksessa keltuaisen väri muuttui kontrolliin verrattuna tummemmaksi ja keltaisemmaksi sinilupiinirehua syötettäessä, joten sinilupiinilla voidaan ehkä vaikuttaa keltuaisen väriin.

Tutkimuksen tavoitteena oli selvittää rajoitetulla kanamäärällä sinilupiinin vaikutuksia munantuotantoon ja kanamunan laatuun, erityisesti keltuaisen väriin.

\section{AINEISTOT JA MENETELMÄT}

Kokeessa oli 108 LSL-kanaa, jotka kokeen alkaessa olivat 40 viikon ikäisiä. Kanat pidettiin perinteisissä kolmen kanan häkeissä. Koe tehtiin MTT:n tutkimuskanalassa kesä-heinäkuussa 2011. Kuusi vierekkäistä kolmen kanan häkkiä muodostavat yhden ruokintakerranteen. Koeyksiköitä oli yhteensä 6 ja kutakin ruokintakäsittelyä kohti oli 2 ruokintakerrannetta. Kokeessa oli kolme ruokintakäsittelyä: soijapohjainen kontrollirehu sekä munitusrehut, joissa soijaa oli korvattu sinilupiinilla $8 \%$ ja $16 \%$.

Koerehut sisälsivät ohraa, vehnää, kauraa, soijarouhetta, sinilupiinia, rypsiöljyä sekä tarvittavia kivennäis- ja hivenaineita sekä vitamiineja ja puhtaita aminohappoja. Rehut eivät sisältäneet väripigmenttiaineita. Koerehut optimoitiin energia-, raakavalkuais-, aminohappo- ja vitamiini- ja kivennäisainepitoisuuksiltaan samanlaisiksi ja höyryrakeistettiin 4 mm:n seulalla.

Koe kesti 6 viikkoa. Kahden viikon totutuskauden jälkeen aloitettiin 4 viikon tuotannonseuranta. Munantuotanto (munien lukumäärä ja paino) kirjattiin päivittäin koeyksiköittäin neljän viikon ajan. Rehunkulutus laskettiin neljän viikon ajalta lisätyn rehun ja jätteiden erotuksena kokeen lopussa.

Munien laatumääritys (ominaispaino, kuoren kestävyys ja valkuaisen korkeudesta laskettu Haughluku) tehtiin 8 munasta joka koeyksiköstä kokeen viimeisellä viikolla. Keltuaisen väri määritettiin kokeen alussa ja kokeen aikana viikoittain yhteensä 4 kertaa. Keltuaisen väri kokeen alussa edusti keltuaisen väriä, silloin kun lintujen rehu sisältää väriainetta. Määritys tehtiin 6 munasta joka koeyksiköstä. Väri määritettiin sekä väripaletilla että Minoltan mittarilla (Minolta CM-508d spektofotometri). Minoltan mittarilla mitatut arvot olivat $L^{*}(0=$ musta, $100=$ valkoinen $), a^{*}(-100=$ vihreä, $100=$ punainen $)$ ja $b^{*}(-100=$ sininen, $100=$ keltainen).

\section{TULOKSET JA TULOSTEN TARKASTELU}

Koerehujen raaka-aineet ja kemiallinen analysoitu koostumus on esitetty taulukossa 1. Rehut olivat raakakuitu ja -rasva sekä typettömät uuteaineet -pitoisuuksia lukuun ottamatta koostumukseltaan hyvin samanlaisia. Lisättäessä sinilupiinia rehuun sekä raakarasvan että raakakuiden pitoisuus suureni samalla typettömien uuteaineiden pitoisuus pieneni.

Taulukko 1. Kokeessa käytettyjen rehujen raaka-aineet ja kemiallinen analysoitu koostumus

\begin{tabular}{lccc} 
& 1 & 2 & 3 \\
& Kontrolli & Sinilupiini 8 \% & Sinilupiini 16\% \\
\hline Ohra & 24,47 & 21,7 & 19 \\
Vehnä & 26,85 & 23,82 & 20,8 \\
Kaura & 23,24 & 20,63 & 18,01 \\
Härkäpapu & 0 & 0 & 0 \\
Soijarouhe & 13,55 & 11,9 & 10,18 \\
Sinilupiini & 0 & 8 & 16 \\
Rypsiöljy & 0,09 & 2,05 & 4 \\
\hline
\end{tabular}




\begin{tabular}{lccc}
\hline Monokalsiumfosfaatti & 1,45 & 1,4 & 1,35 \\
Ruokintakalkki & 9,35 & 9,31 & 9,27 \\
Ruokasuola & 0,4 & 0,4 & 0,4 \\
Hivenaineseos & 0,2 & 0,2 & 0,2 \\
Vitamiiniseos & 0,14 & 0,14 & 0,14 \\
Metioniini & 0,13 & 0,16 & 0,18 \\
Lysiini & 0,05 & 0,16 & 0,26 \\
Treoniini & 0 & 0,06 & 0,13 \\
Seleeni-seos & 0,08 & 0,08 & 0,08 \\
\hline Kuiva-aine (\%) & 90,8 & 90,55 & 90,61 \\
Tuhka & 132,7 & 136,4 & 137,1 \\
Raakavalkuainen & 172,1 & 163,8 & 165,1 \\
Raakarasva & 26,4 & 51,5 & 77,3 \\
Raakakuitu & 53,1 & 58 & 61,3 \\
Typettömät uuteaineet & 615,7 & 590,3 & 559,2 \\
\hline
\end{tabular}

Munintaprosentti ja munien tuotanto (g/pv/kana) paranivat kontrolliin verrattuna lisättäessä sinilupiinia rehuun (taulukko 2). Ruokintaryhmien väliset erot munintaprosentissa ja munien tuotannossa voivat selittyä osittain eläinten välisellä vaihtelulla, osittain sinilupiinin munintaprosenttia ja munien tuotantoa parantavalla vaikutuksella. Rehunkulutus (g/pv/kana) ei eronnut ryhmien välillä, joten sinilupiinin lisääminen rehuun vähensi rehunmuuntosuhdetta (rehua kg/ muna-kg). Rehun sinilupiinin määrällä (8 \% vs 16 \%) ei ollut vaikutusta munintaprosenttiin. Munien paino, ominaispaino ja kuorenkestävyys eivät eronneet ryhmien välillä. Sinilupiinirehuilla ruokitut linnut munivat Haugh-luvultaan suurempia munia kuin kontrolliryhmä. Kuitenkin Prinsloon et al. (1992) ja Quarantellin (1993) kokeissa Haugh-luvut eivät eronneet valkolupiinia ja makeaa lupiinia syöneiden lintujen ja kontrolliryhmien välillä.

Taulukko 2. Rehun sinilupiinipitoisuuden vaikutus munivien kanojen tuotantotuloksiin sekä munien laatuun.

\begin{tabular}{lccccc}
\hline & 1 & 2 & 3 & SEM & Kontrastien P-arvot \\
& Kontrolli & Sinilupiini 8 \% & Sinilupiini 16 \% & & C1 \\
C2
\end{tabular}

SEM = keskiarvon keskivirhe.

Ryhmien 1 ja 3 havaintojen lukumäärä $\mathrm{N}=16$. Ryhmän 2 havaintojen lukumäärä $\mathrm{N}=15$ ja SEM=1,033*SEM

a-b) Keskiarvot, joilla on yhteinen yläindeksi, eivät poikkea toisistaan tilastollisesti merkitsevästi 5 \% riskitasolla (Tukeyn testi).

C1: kontrollirehu vs. sinilupiinirehut

C2: rehussa $8 \%$ sinilupiinia vs rehussa $16 \%$ sinilupiinia

*** $\mathrm{P}<0,0001, * * \mathrm{P}<0,01, * \mathrm{P}<0,05$ ja o $\mathrm{P}<0,10$

Samoin kuin Hammersjoin ja Steenfeldin (2005) tutkimuksessa keltuaisen väri tummeni kontrolliin verrattuna sinilupiini rehuja syötettäessä (taulukko 3). Tuotannonseurannan ensimmäisellä ja toisella viikolla keltuaisen väri ei eronnut sinilupiinirehuja syöneiden ryhmien välillä (8 \% vs $16 \%$ ), mutta kolmannella viikolla väri tummeni sinilupiinin määrän lisääntyessä rehussa. Toisaalta ennen varsinaista tuotannonseurausta sinilupiinirehuja syöneet kanat munivat keltuaisen väriltään tummempia munia kuin kontrolliryhmä, millä saattoi olla vaikutusta tuloksiin tuotannonseurannan aikana.

Keltuaisen tummuus (musta/valkoinen, L*) ei eronnut ruokintaryhmien välillä ennen tuotannonseurannan aloitusta eikä tuotannonseurannan ensimmäisellä ja neljännellä viikolla. Toisella viikolla sinilupiinirehua syöneiden kanojen keltuaiset olivat tummempia kuin kontrolliryhmän keltuaiset, mutta sinilupiinin määrällä (8 \% vs $16 \%$ ), ei ollut vaikutusta keltuaisen tummuuteen. Kolmannella viikolla sinilupiinia 
syöneiden lintujen keltuaiset olivat tummempia kuin kontrolliryhmän keltuaiset, mutta ero oli merkitsevä vain kontrolliryhmän ja ryhmän, jonka rehu sisälsi 16 \% sinilupiinia, välillä. Kokeen alussa väriaineen vaikuttaessa keltuaiset olivat tummuudeltaan samalla tasolla kuin sinilupiinirehuja syöneiden lintujen keltuaiset.

Keltuaisen punaisuus (vihreä/punainen $\mathrm{a}^{*}$ ) ei eronnut ryhmien väillä ennen tuotannonseurannan aloitusta eikä tuotannonseurannan toisella ja neljännellä viikolla. Ensimmäisellä ja kolmannella viikolla keltuaiset olivat punaisempia verrattuna kontrolliryhmään kanojen syödessä sinilupiinirehuja. Kolmannella viikolla ero oli merkitsevä vain kontrolliryhmän ja ryhmän, jonka rehu sisälsi $16 \%$ sinilupiinia, välillä. Kokeen alussa väriaineen vaikuttaessa keltuaisen väriin keltuaiset olivat huomattavasti punaisempi kuin lintujen syödessä sinilupiinirehuja.

Keltuaisen keltaisuus (sininen/keltainen b*) ei eronnut ryhmien väillä ennen tuotannonseurannan aloitusta ja tuotannonseurannan neljännellä viikolla. Ensimmäisellä, toisella ja kolmannella viikolla kanojen syödessä sinilupiinirehuja keltuaiset olivat keltaisempia verrattuna kontrolliryhmään. Ensimmäisellä viikolla sinilupiinin määrällä (8 \% vs $16 \%$ ), ei ollut vaikutusta keltuaisen keltaisuuteen. Toisella viikolla ero oli merkitsevä vain kontrolliryhmän ja ryhmän, jonka rehu sisälsi $16 \%$ sinilupiinia, välillä. Kolmannella viikolla ero oli merkitsevä kaikkien ryhmien välillä. Kokeen alussa väriaineen vaikuttaessa keltuaisten keltaisuus oli samalla tasolla kuin lintujen syödessä sinilupiinirehuja.

Taulukko 3. Rehun sinilupiinipitoisuuden vaikutus keltuaisen väriin.

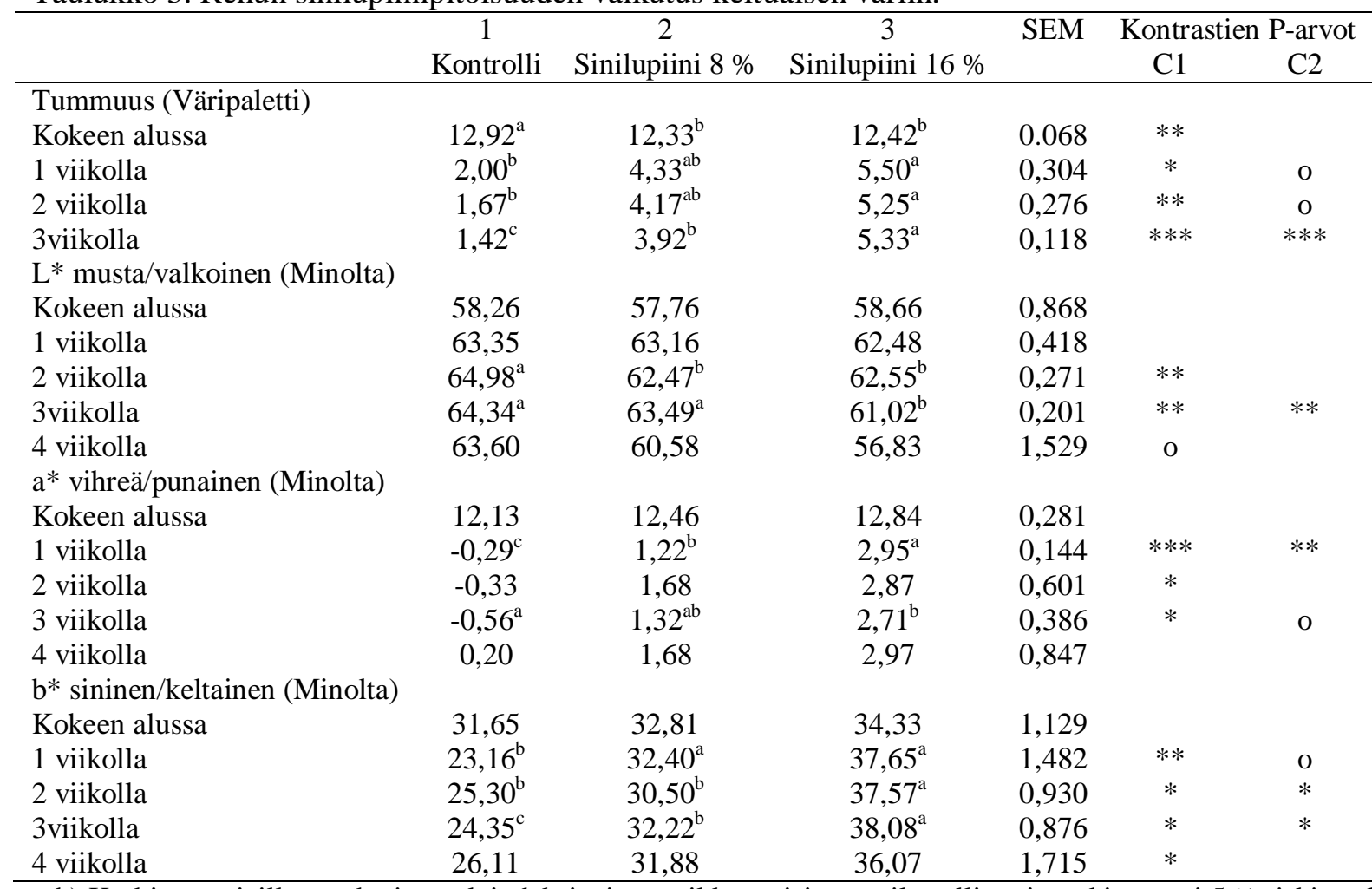

a-b) Keskiarvot, joilla on yhteinen yläindeksi, eivät poikkea toisistaan tilastollisesti merkitsevästi 5 \% riskitasolla (Tukeyn testi)

SEM = keskiarvon keskivirhe

$* * * \mathrm{P}<0,0001, * * \mathrm{P}<0,01, * \mathrm{P}<0,05$ ja o $\mathrm{P}<0,10$

\section{JOHTOPÄÄTÖKSET}

Kontrolliryhmän munintaprosentti oli huomattavasti pienempi kuin sinilupiiniryhmien munintaprosentit. Munien tuotanto (g/pv/kana) parani lintujen syödessä sinilupiinia samalla rehunmuuntosuhde (kg/muna-kg) pieneni, koska rehunkulutus (g/pv/kana) ei eronnut ryhmien välillä. Parantuneet munintaprosentti ja munien tuotanto (g/pv/kana) saattoivat johtua osittain eläinten välisestä vaihtelusta, ei niinkään sinilupiinin munintaa parantavasta vaikutuksesta. Sinilupiinirehuilla ruokitut linnut munivat Haugh-luvultaan suurempia munia kuin kontrolliryhmä. Sinilupiinin määrällä (8 \% vs $16 \%$ ) ei ollut vaikutusta tuotantotuloksiin. 
Sinilupiini näyttäisi maistuvan kanoille ja sopivan hyvin munivien kanojen valkuaisrehuksi. Sinilupiinia voidaan tämän kokeen perusteella käyttää munivien kanojen dieetissä ainakin 16 \% ilman, että tuotantotulokset huononevat. Sinilupiinia syövät kanat voivat munia keltuaisen väriltään, punaisempi munia kuin tavanomaista rehua syövät kanat.

\section{KIRJALLISUUS}

Hammershøj, M. \& Steenfeldt, S. 2005. Effects of Blue Lupin (Lupinus angustifolius) in Organic Layer Diets and Supplementation with Foraging Material on Egg Production and Some Egg Quality Parameters. Poultry Science 84:723 - 733 s.

Palander, S., Laurinen, P., Perttilä, P., Valaja, J. \& Partanen, K. 2006. Protein and amino aciddigestibility and metabolizable energy value of pea (Pisum sativum). faba bean (Vicia faba) and lupin (Lupinus angustifolius) seeds for tukeys of different age. Animal Feed Science and Technology 127: 89 $100 \mathrm{~s}$.

Prinsloo, J. J., Smith, G. A. \& Rode, W. 1992. Sweet white Lupinus albus (cv Buttercup) as a feedstuff for layers. British Poultry Science 33: 525 - 530 s.

Quarantelli, A. 1993. Composition of white lupin seed meal (Lupinus albus, L.) and its use in feeding laying hens. Teoksessa: Proceedings of the 10th national congress, Scientific Association of Animal Production, Bologna, Italy, 31 May-3 June 1993. 499 - 505 s. 